\title{
PELAKSANAAN PEMBELAJARAN BERBASIS KURIKULUM 2013 DI TK IT QURROTA A'YUN BABADAN PONOROGO
}

\author{
M. FADLILLAH \\ PG-PAUD Universitas Muhammadiyah Ponorogo \\ Email : fadly_ok@yahoo.co.id
}

\begin{abstract}
Abstrak
Artikel ini bertujuan untuk : 1) mengetahui pelaksanaan pembelajaran berbasis Kurikulum 2013 di TK IT Qurrota A'yun Babadan Ponorogo; 2) mengetahui faktor-faktor pendukung dan penghambat pelaksanaan pembelajaran berbasis Kurikulum 2013 di TK IT Qurrota A'yun Babadan Ponorogo. Metode penelitian yang digunakan adalah deskriptif kualitatif. Pengumpulan data dilakukan dengan teknik wawancara, observasi, dan dokumentasi terhadap kegiatan pembelajaran sehari-hari di sekolah. Adapun teknik pengujian datanya dilakukan dengan model tri angulasi. Hasil penelitian menunjukkan bahwa: 1) pelaksanaan pembelajaran berbasis kurikulum 2013 di TK IT Qurrota 'Ayun Babadan Ponorogo telah berjalan dengan baik. Tahapan pelaksanaanya yaitu menyusun perencanaan pembelajaran dalam bentuk Program Semester (Promes), rencana Pelaksanaan Pembelajaran Mingguan (RPPM), dan Rencana Pelaksanaan Pembelajaran Harian (RPPH). Adapun pelaksanaan pembelajaran dilakukan secara tematik dengan pendekatan saintifik melalui model pembelajaran sentra. 2) Faktor-faktor pendukung pelaksanaan pembelajaran yaitu kepala sekolah sudah berpengalaman dalam Kurikulum 2013, mayoritas guru masih muda-muda, dan sudah menggunakan model pembelajaran sentra. Adapun faktor penghambatnya ialah fasilitas pembelajaran masih terbatas dan administrasi pembelajaran belum tersusun secara rapi.
\end{abstract}

\section{Kata kunci: Pembelajaran, Kurikulum 2013, dan Pendidikan Anak Usia Dini}

\begin{abstract}
This article aims to know : 1) the implementation of learning based on Curriculum 2013 in TK IT Qurrota A'yun Babadan Ponorogo. 2) the supporting and inhibiting factors of learning based on Curriculum 2013 in TK IT Qurrota A'yun Babadan Ponorogo. This study method used descriptive qualitative method. The collecting data was done by interview, observation and documentation of activities of daily lessons at the school. The technique of test data was done by triangulation models. The results of this study indicated that: 1) the implementation of learning based on Curriculum 2013 in TK IT Qurrota A'yun Babadan Ponorogo had gone well. The steps of the implementation were: planning of learning in the form of the semester program (Promes), weekly lesson plan (RPPM), and daily lesson plan (RPPH), and the study conducted thematically with the scientific approach through learning model centers. 2) Factors supporting the implementation of learning that is the principal has experience in the Curriculum 2013, the majority of teachers are still young, and already using the learning model centers. The inhibiting factor is the learning facilities are still limited and the administration of learning has not been neatly arranged.
\end{abstract}

Keywords: Learning, Curriculum 2013, and Early Childhood Education 


\section{PENDAHULUAN}

Kurikulum dalam pembelajaran memiliki kedudukan yang sangat penting, termasuk dalam pendidikan anak usia dini. Selain berfungsi sebagai pedoman pembelajaran, kurikulum juga dapat menentukan keberhasilan proses pembelajaran. Dalam Undang-Undang Nomor 20 Tahun 2003 Pasal 1 alenia 19 disebutkan bahwa kurikulum ialah seperangkat ren-cana dan pengaturan mengenai isi dan bahan pelajaran serta cara yang digunakan sebagai pedoman penyelenggaraan kegiatan belajar mengajar (Depdiknas, 2003). Menurut Hilda Taba sebagaimana dikutip Sanjaya (2008:7) menyebutkan: 'A curriculum ia a plan for learning; therefore, what is known about the learning process and the development of the individual has bearing on the shaping of $a$ curriculum'.

Kurikulum

merupakan

perencanaan pembelajaran yang memuat berbagai petunjuk belajar serta hasil yang diharapkan. Melalui kurikulum berbagai program yang ditetapkan satuan pendidikan dapat dijalankan dengan baik sesuai yang direncanakan. Sejalan dengan itu, Sholeh Hidayat (2013:25-26) mengungkapkan bahwa fungsi kurikulum adalah sebagai alat untuk mencapai tujuan-tujuan yang diinginkan dan sekaligus sebagai pedoman dalam mengatur segala kegiatan pendidikan setiap hari.

Menurut Fadlillah (2017:44) kurikulum merupakan sebuah wadah yang akan menentukan arah pendidikan. Artinya, kurikulum menjadi salah satu yang menentukan keberhasilan pendidikan. Fadlillah (2014:2) menambahkan bahwa kurikulum merupakan ujung tombak bagi terlaksananya kegiatan pendidikan. Tanpa adanya kurikulum mustahil pendidikan dapat berjalan dengan baik, efektif dan efisien sesuai yang diharapkan.

Dalam pendidikan anak usia dini, kurikulum yang diberlakukan saat ini adalah Kurikulum 2013. Pemberlakuan kurikulum 2013 ini didasarkan pada Permendikbud No. 146 Tahun 2014 tentang Kurikulum 2013 PAUD. Meskipun sudah ditetapkan melalui peraturan menteri pendidikan dan kebudayaan, namun masih terdapat banyak satuan pendidikan PAUD yang belum mengimplementasikannya dalam pembelajaran. Salah satunya ialah di daerah Kabupaten Ponorogo. Menurut informasi yang peneliti dapatkan dari guru-guru PAUD setempat, dari total 984 satuan pendidikan anak usia dini, sampai tahun 2016 belum ada 5\% yang telah menerapkan Kurikulum 2013 dalam pembelajaran. Alasan yang sering dikeluhkan guru adalah belum dapat memahami bentuk dan sistematika Kurikulum 2013, terutama dalam menyiapkan perangkat pembelajarannya.

Berkaitan dengan persoalan tersebut, sebenarnya ada satu lembaga pendidikan anak usia dini yang telah menerapkan Kurikulum 2013 di Kabupaten Ponorogo. Satuan pendidikan tersebut adalah TK IT Qurrota A'yun Babadan Ponorogo. Satuan pendidikan ini diyakini sebagai satu-satunya lembaga pendidikan anak usia dini di Kabupaten Ponorogo yang menerapkan Kurikulum 2013 pertama kali, yakni mulai tahun 2015 .

Oleh karena itu, artikel ini berusaha mendeskripsikan pelaksanaan pembelajaran berbasis Kurikulum 2013 di TK IT Qurrota A'yun Babadan Ponorogo, beserta berbagai faktor- 
faktor pendukung dan penghambat pelaksanaan pembelajaran tersebut. Dengan demikian, masing-masing satuan pendidikan anak usia dini, khususnya di Kabupaten Ponorogo dapat menjadikan hasil penelitian ini sebagai rujukan maupun pembanding dalam menerapkan Kurikulum 2013 dalam pembelajaran pendidikan anak usia dini.

\section{METODE PENELITIAN}

Penelitian ini merupakan penelitian lapangan dengan menggunakan metode deskripsi kualitatif. Salah satu ciri penelitian kualitatif yaitu menggambarkan kondisi secara alamiah (Sugiyono, 2011, pp. 89). Dalam penelitian ini berusaha menggambarkan dengan sesungguhnya berbagai aktivitas pembelajaran di TK IT Qurrota A'yun Babadan Ponorogo. Mulai dari kegiatan perencanaan pembelajaran sampai tahap penilaian pembelajaran.

Metode pengumpulan data dalam penelitian ini dilakukan dengan menggunakan tiga cara, yaitu observasi, wawancara, dan dokumentasi. Kegiatan observasi dilakukan pada saat proses pembelajaran berlangsung. Dalam observasi ini peneliti melihat kesesuaian antara perencanaan yang telah dibuat guru di TK IT Qurrota A'yun Babadan Ponorogo. Bentuk observasi ini mengacu pada pendapat Anas Sudijono (2005:76) yang menyebutkan bahwa observasi merupakan cara menghimpun bahan-bahan keterangan (data) yang dilakukan dengan mengadakan pengamatan dan pencatatan secara sistematis terhadap fenomena-fenomena yang sedang dijadikan sasaran pengamatan.

Kegiatan wawancara peneliti lakukan kepada kepala sekolah dan sebagian guru di TK IT Qurrota A'yun Babadan Ponorogo. Dalam wawancara ini peneliti berusaha mendapatkan data berkaitan dengan faktor-faktor pendukung dan berbagai hambatan dalam pelaksanaan pembelajaran berbasis Kurikulum 2013 di TK IT Qurrota A'yun Babadan Ponorogo.

Adapun kegiatan dokumentasi dilakukan dalam rangka mendapatkan data yang berhubungan dengan proses pembelajaran, seperti program semester, rencana pelaksanaan pembelajaran mingguan, rencana pelaksanaan pembelajaran harian, dan bentuk-bentuk penilaian yang dilakukan oleh guru di TK IT Qurrota A'yun Babadan Ponorogo. Kegitan dokumentasi yang peneliti lakukan ini mengacu pada pendapat Suharsimi (2002:206) yang menyebutkan bahwa dokumentasi ialah mencari data mengenai hal-hal atau variabel yang berupa catatan, transkrip, buku, surat kabar, majalah, prasasti, notulen rapat, legger, agenda dan sebagainya.

Teknik analisis data yang digunakan dalam penelitian ini ialah model Miles dan Huberman, di antaranya: redukasi data (data reduction), penyajian data (data display), dan kesimpulan/verifikasi (conclusion/verification) (Sugiyono, 2011:246). Reduksi data dimaksudkan untuk merangkum atau memilih secara teliti dan rinci data-data yang telah didapatkan di TK IT Qurrota A'yun Babadan Ponorogo, sehingga dapat memberikan gambaran yang lebih jelas terhadap data pokok yang diperlukan. Setelah itu, data dari hasil reduksi didisplai dalam bentuk tabel atau grafik, supaya lebih terorganisasi dan mudah untuk dipahami, serta dapat ditarik sebuah kesimpulan. 
Adapun kegiatan validasi data dalam penelitian ini dilakukan dengan menggunakan triangulasi. Triangulasi ialah pengecekan data dari berbagai sumber dengan berbagai cara dan berbagai waktu (Sugiyono, 2011:273). Data-data yang telah peneliti dapatkan dari kegiatan observasi, wawancara, maupun dokumentasi di TK IT Qurrota A'yun Babadan Ponorogo dikomparasikan dan diuji dengan berbagai cara dan berbagai waktu.

\section{HASIL DAN PEMBAHASAN}

\section{Pelaksanaan Pembelajaran Berbasis Kurikulum 2013}

Dalam Permendikbud No. 146 Tahun 2014 Pasal 3 ayat 1 disebutkan bahwa Kurikulum 2013 Pendidikan Anak Usia Dini terdiri atas: 1) kerangka dasar kurikulum; 2) struktur kurikulum; 3) pedoman deteksti tumbuh kembang anak; 4) pedoman pengembangan kurikulum tingkat satuan pendidikan; 5) pedoman pembelajaran; 6) pedoman penilaian; dan 7) buku-buku panduan pendidik (Kemendikbud, 2014).

Kerangka dasar kurikulum berisi landasan-landasan yang menjadi dasar dalam penyusunan dan pelaksanaan kurikulum 2013 yang sesuai dengan standar nasional pendidikan, meliputi landasan filosofis, sosiologis, psikopedagogis, teoritis, dan yuridis. Struktur kurikulum merupakan pengorganisasian muatan kurikulum, kompetensi inti, kompetensi dasar, dan lama belajar. Muatan kurikulum di sini dimaknai sebagai program-program pengembangan potensi anak yang mencakup: nilai agama dan moral, fisikmotorik, kognitif, bahasa, sosialemosional, serta seni (Kemendikbud, 2014). Kompetensi inti dimaknai sebagai gambaran pencapaian Standar Tingkat Pencapaian Perkembangan
Anak pada akhir layanan PAUD usia 6 (enam) tahun yang dirumuskan secara terpadu dalam bentuk: kompetensi inti sikap spiritual (KI-1), kompetensi inti sikap sosial (KI-2), kompetensi inti pengetahuan (KI-3), dan kompetensi inti keterampilan (KI-4). Selanjutnya, kompetensi dasar dimaknai sebagai tingkat kemampuan dalam konteks muatan pembelajaran, tema pembelajaran, dan pengalaman belajar yang mengacu pada Kompetensi Inti tersebut (Kemendikbud, 2015).

Adapun pedoman deteksi dini tumbuh kembang anak berisi strategi untuk menemukan hambatan pertumbuhan dan perkembangan pada anak. Pedoman Pengembangan Kurikulum Tingkat Satuan Pendidikan berisi acuan untuk membantu pendidik dalam mengembangkan kurikulum operasional yang kontekstual. Pedoman Pembelajaran berisi strategi-strategi kegiatan pembelajaran yang harus dipahami dan diterapkan oleh pendidik. Pedoman Penilaian berisi acuan untuk melakukan penilaian terhadap proses dan hasil kegiatan anak. Buku-buku Panduan Pendidik berisi panduan operasional pembelajaran di satuan/program PAUD.

Pelaksanaan pembelajaran Kurikulum 2013 di TK IT Qurrota A'yun mulai diterapkan pada tahun pelajaran 2014/2015. Hal ini diungkapkan langsung oleh kepala TK IT Qurrota A'yun Ibu Nur Syamsiyah pada tanggal 22 April 2016. TK ini merupakan satu-satunya lembaga pendidikan anak usia dini di Kabupaten Ponorogo yang telah menerapkan Kurikulum 2013 PAUD. Dalam Pelaksanaan pembelajaran Kurikulum 2013 TK IT Qurrota A'yun Babadan Ponorogo berpedoman pada Permendikbud No. 146 tahun 2014 
tentang Kurikulum 2013 PAUD dan Permendikbud No. 137 tahun 2014 tentan Standar Nasional Pendidikan Anak Usia Dini.

Dalam kurikulum 2013 pembelajaran pendidikan anak usia dini dilakukan dengan tiga tahap, yaitu membuat perencanaan pembelajaran, pelaksanaan pembelajaran dan kegiatan penilaian (Kemendikbud, 2015). Ketiga tahapan tersebut harus dilakukan oleh satuan pendidikan atau tenaga pendidik masing-masing dengan memperhatikan potensi daerah masing-masing. Artinya, dalam kegiatan pembelajaran yang harus memenuhi tiga tahap tersebut. Adapun penjelasan dari masing-masing tahap sebagai berikut:

\section{a. Perencanaan pembelajaran}

Perencanaan pembelajaran adalah sebuah acuan yang disusun untuk memperlancar proses pembelajaran. Dalam perencanaan pembelajaran terdiri atas berbagai program yang akan dilaksanakan selama kegiatan pembelajaran. Perencanaan pembelajaran Kurikulum 2013 pendidikan anak usia dini ini mencakup program semester (Promes), rencana pelaksanaan pembelajaran mingguan (RPPM) dan rencana pelaksanaan pembelajaran harian (RPPH). Adapun perencanaan pembelajaran Kurikulum 2013 di TK IT Qurrota A'yun Babadan Ponorogo yaitu:

1) Program semester (Promes)

Program semester adalah program pembelajaran yang memuat kompetensi dasar, tema, sub tema, dan alokasi waktu. Komponen-komponen tersebut minimal harus ada dalam program semester. Adapun program semester di TK Qurrota A'yun Babadan Ponorogo sama seperti ketentuan yang ditetapkan, yakni berisi kompetensi dasar, tema, sub tema, dan alokasi waktu yang disediakan. Berikut ini salah satu bentuk program semester di TK IT Qurrota A'yun Babadan Ponorogo:

Tabel 1. Progam Semester (Promes) TK IT Qurrota A'yun Babadan Ponorogo

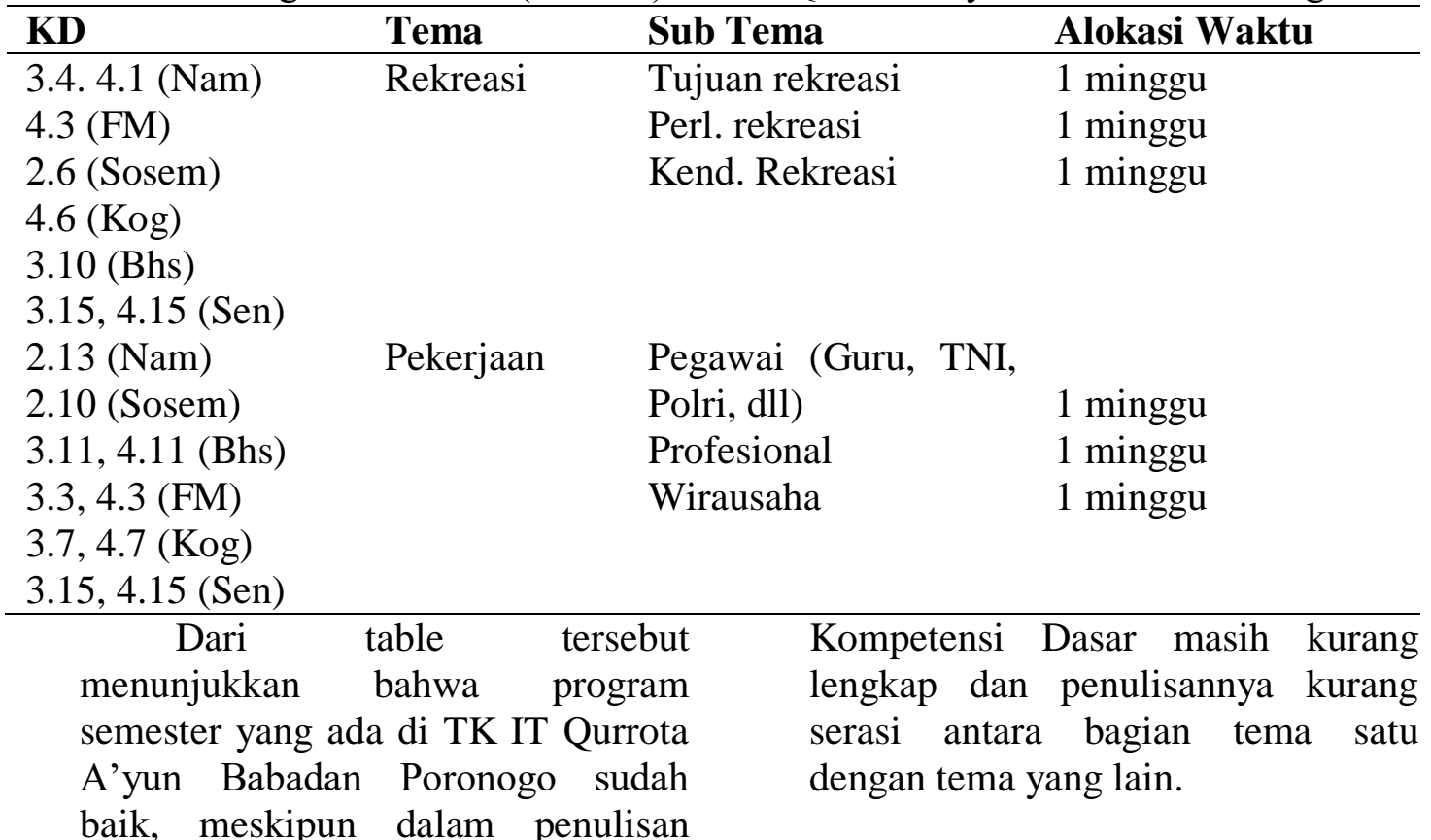


2) Rencana pelaksanaan pembelajaran mingguan (RPPM) Rencana pelaksanaan pembelajaran mingguan adalah sebuah rencana pembelajaran yang dijabarkan dari program semester yang berisi kegiatan-kegiatan dalam rangka mencapai indikator yang telah direncanakan dalam satu minggu sesuai dengan keluasan pembahasan tema dan subtema. Adapun rencana pelaksanaan pembelajaran mingguan (RPPM) di TK IT Qurrota A'yun Babadan Ponorogo dibuat dengan jaringan tema yang akan disampaikan dalam waktu satu minggu. Rencana pelaksanaan pembelajaran mingguan ini terdiri dari tema dan sub tema, serta indikator-indikator dalam sub tema pembelajaran. Selain itu, dalam pembuatan rencana pelaksanaan mingguannya menggunakan model pembelajaran sentra, meliputi: sentra persiapan, sentra alam, sentra seni dan olah raga, serta sentra kreativitas dan balok. Adapun contoh RPPM di TK IT Qurrota A'yun Babadan Ponorogo sebagai berikut:

Tabel 2. RPPM TK IT Qurrota A'yun Babadan Ponorogo

Tema : Rekreasi

Sub tema : Tujuan Rekreasi

Sub-sub tema : Pegunungan dan kebun binatang

Semester/minggu : II/I

\begin{tabular}{lll}
\hline Kelas Sentra & KD & Rencana Kegiatan \\
\hline Seni dan olah & $3.1,4.1(\mathrm{Nam})$ & Do'a melihat keindahan \\
raga & $2.5(\mathrm{Sosem})$ & Percaya diri dan tidak cengeng \\
& $3.5,4.5(\mathrm{Kog})$ & Mencari jejak jalan ke gunung \\
& $3.3,4.3(\mathrm{FM})$ & Berlari ke depan dan ke samping $5 \mathrm{~m}$ \\
& $3.11,4.11(\mathrm{Bhs})$ & Menyanyi lagu ke puncak gunung \\
Alam & $3.15,4.15(\mathrm{Seni})$ & Menggambar gurung \\
& $1.2(\mathrm{Nam})$ & Tidak menyakiti binatang \\
& $2.6(\mathrm{Sosem})$ & Menghindari binatang berbahaya \\
& $2.3(\mathrm{Kog})$ & Membuat kandang hewan \\
& $3.3,4.3(\mathrm{FM})$ & Meniru gerakan binatang \\
& $3.15,4.15(\mathrm{Seni})$ & Melukis gambar binatang \\
\hline
\end{tabular}

3) Rencana pelaksanaan pembelajaran harian (RPPH)

Rencana pelaksanaan pembelajaran harian adalah rencana pembelajaran yang dijabarkan dari perencanaan mingguan. rencana pelaksanaan pembelajaran harian memuat kegiatan-kegiatan pembelajaran, baik yang dilaksanakan secara individual, kelompok, maupun klasikal dalam satu hari. Komponen-komponen dalam RPPH yaitu hari, tanggal, waktu, materi/indikator, kegiatan pembelajaran, alat/sumber belajar, dan penilaian perkembangan (Kemendikbud, 2015).

Adapun rencana pelaksanaan pembelajaran harian (RPPH) di TK IT Qurrota A'yun Babadan Ponorogo telah memuat berbagai komponen yang telah ditentukan, di antaranya: hari/tanggal, kelompok/usia, semester, tema dan sub tema, materi, alat dan bahan, kegiatan pembuka, 
inti, penutup, dan rencana penilaian. Dalam pembuatan RPPH ini TK IT Qurrota A'yun telah berkreasi dengan menyusun rencana pelaksanaan pembelajaran harian tersebut dengan menggunakan satu lembar kertas. Padahal seharusnya sebuah rencana pelaksanaan pembelajaran harian minimal membutuhkan dua lembar kertas.
Dengan menggunakan satu lembar kertas ini, TK IT Qurrota A'yun dapat menghemat pengeluaran, khususnya dalam penggunaan kertas. Namun demikian, rencana pelaksanaan pembelajaran hariannya terlihat kurang rapi, karena font dan spasinya terlalu kecil. Berikut contoh RPPH di TK IT Qurrota A'yun Babadan Ponorogo:

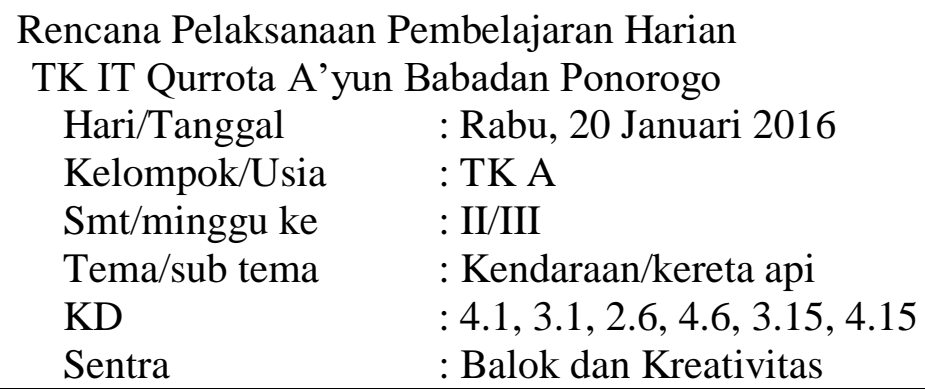

Materi yang masuk dalam kegiatan:

1. Mengucapkan kalimat thayyibah

2. Tidak bermain di lintasan kereta api

3. Bernyanyi naik kereta api

4. Menggunting gambar kereta api

5. Membuat kereta api dari balok

6. Menggambar kereta api

Materi yang masuk dalam pembiasaan

1. Doa sebelum dan sesudah belajar

2. Salam dan absensi

3. Hafalan surat, hadits, dan doa sehari-hari

4. Mencuci tangan, makan snack, istirahat

5. Kelasa baca

6. Makan siang

7. Wudlu dan latihan shalat

a. Pembukaan

1. Bernyanyi/tepuk

2. Doa sebelum belajar

3. Hafalan surat, hadits, do'a

4. Diskusi

5. Mengenalkan aturan bermain

b. Inti

1. Anak mengamati

2. Anak bertanya

3. Anak mengumpulkan informasi

4. Anak menalar
Alat dan bahan:

1. Balok

2. Krayon dan gunting

3. Kertas dan spidol
Circle time *)

1. Latihan upacara

2. Motorik kasar

3. Praktik shalat dhuha

4. Senam

*) lingkari kegiatan yang sesuai

5. Anak mengkomunikasikan

c. Penutup

1. Menanyakan perasaan selama anak bermain di lembaga

2. Menyimpulkan kegiatan yang sudah dimainkan hari ini

3. Pemberian tugas kepada anak

4. Berdo'a setelah belajar.

\section{b. Pelaksanaan pembelajaran}

Pelaksanaan pembelajaran merupakan kegiatan 
mengembangkan berbagai potensi anak supaya mencapai perkembangan yang diharapkan. Pelaksanaan pembelajaran harus disesuaikan dengan rencana pelaksanaan pembelajaran harian (RPPH). Pada saat pembelajaran pula pendidik menggunakan berbagai pendekatan, strategi, dan metode pembelajaran untuk mencapai tujuan pembelajaran yang ditentukan. Dalam kurikulum 2013 PAUD pendekatan pembelajaran digunakan dengan pendekatan saintifik. Ciri-ciri dari pendekatan ini ialah pembelajaran dilakukan dengan kegiatan mengamati, menanya, mencoba, menalar, dan mengkomunikasikan (Kemendikbud, 2014).

Kegiatan pembelajaran dengan pendekatan ini juga dilaksanakan di TK IT Qurrota A'yun Babadan Ponorogo, baik di TK kelas A maupun kelas B. Adapun tahapantahapan pembelajarannya dapat dijelaskan sebagai berikut:

1) Kegiatan pembukaan

Kegiatan pembukaan adalah kegiatan untuk memulai pembelajaran sebelum masuk pada materi yang akan diberikan (Kemendikbud, 2015). Pembukaan dimaksudkan untuk menyiapkan dan mengkondisikan peserta didik supaya siap menerima materi pembelajaran. Dalam pembukaan ini yang disampaikan oleh pendidik ialah salam dan do'a pembuka, bernyanyi, dan memotivasi peserta didik.

Adapun kegiatan pembukaan pembelajaran di TK IT Qurrota A'yun Babadan Ponorogo dilakukan dengan kegiatan bernyanyi, do'a sebelum belajar, hafalan surat hadits dan do'a sehari-hari, diskusi awal tentang tema, serta mengenalkan aturan-aturan dalam bermain. Dalam kegiatan pembukaan ini dibutuhkan waktu lebih kurang $10-15$ menit. Setelah itu, kegiatan inti dilaksanakan sesuai dengan rencana yang ditentukan.

2) Kegiatan inti

Kegiatan inti merupakan kegiatan pokok pembelajaran (Kemendikbud, 2015), tema-tema maupun sub tema pembelajaran disampaikan pada kegiatan ini. Dalam kegiatan inti guru dapat menggunakan berbagai strategi dan metode pembelajaran sesuai dengan kebutuhan. Proses di kegiatan inti sangat menentukan ketercapaian tujuan pembelajaran.

Adapun di TK IT Qurrota A'yun Babadan Ponorogo, kegiatan ini ditandai dengan proses mengamati, menanya, mengumpulkan informasi, menalar, dan mengkomunikasikan. Pada proses ini pendidik berperan sebagai fasilitator dan pengamat berbagai aktivitas yang dilakukan oleh anakanak. Peserta didik dibiarkan melakukan aktivitasnya sendiri sesuai dengan keinginan dan imajinasinya.

Pada kegiatan inti pembelajaran materi-materi yang menjadi pokok pembelajaran harus disampaikan dan dipelajari oleh anak-anak melalui aktivitas bermain. Dengan kata lain, tema dan sub tema maupun sub-sub tema dapat dilakukan dengan kegiatan bermain. Melalui kegiatan ini diharapkan peserta didik dapat mengembangkan berbagai potensi yang dimilikinya, seperti moral agama anak, sosial 
emosional, kognitif, bahasa, fisik motorik dan seni.

3) Kegiatan penutup

Kegiatan penutup adalah kegiatan akhir dalam pembelajaran. Pada kegiatan ini biasanya dimaksudkan untuk mengetahui tingkat pemahaman peserta didik dalam menyerap dan menerima materi yang dipelajari. Selain itu, dimaksudkan untuk merangkum dan menyimpulkan kegiatan pembelajaran yang telah dilakukan.

Pada kegiatan ini para pendidik di TK IT Qurrota A'yun Babadan Ponorogo selalu menekankan kembali kepada anak-anak mengenai pengalaman pembelajaran yang dilakukan. Hal ini dilakukan dalam rangka memberikan pemahaman kepada anak terkait dengan tema pembelajaran yang telah dipelajari untuk dapat dijadikan pedoman dalam keseharian anak.

Adapun dalam kegiatan penutup pembelajaran di TK IT selalu menekankan kembali kepada anak-anak mengenai pengalaman pembelajaran yang dilakukan. Hal ini dilakukan dalam rangka memberikan pemahaman kepada anak terkait dengan tema pembelajaran yang telah dipelajari untuk dapat dijadikan pedoman dalam keseharian anak.

Adapun dalam kegiatan penutup pembelajaran di TK IT Qurrota A'yun Babadan Ponorogo dilakukan dengan menanyakan perasaan anak selama bermain, berdiskusi atau menanyakan kegiatan yang sudah dilakukan anak dan yang paling disukai, memberi tugas kepada anak-anak, serta diakhiri dengan doa penutup pembelajaran.

\section{c. Penilaian pembelajaran}

Penilaian pembelajaran adalah suatu kegiatan yang dimaksudkan untuk mengetahui pencapaian perkembangan anak secara keseluruhan (Kemendikbud, 2015). Penilaian ini dilakukan oleh pendidik bersamaan dengan berlangsungnya kegiatan pembelajaran. Menurut Permendikbut No. 137 Pasal 19 disebutkan bahwa penilaian pembelajaran harus dilakukan dengan menggunakan prinsip edukatif, otentik, obyektif, akuntabel, dan transparan (Kemendikbud, 2014). Prinsip-prinsip tersebut juga telah diterapkan di TK IT Qurrota A'yun Babadan Ponorogo dalam melaksanakan penilaian pembelajaran.

Adapun teknik-teknik penilaian pembelajaran dalam Kurikulum 2013 yaitu berupa observasi, percakapan, catatan anekdot, unjuk kerja, hasil karya dan penugasan (Kemendikbud, 2015). Di TK IT Qurrota A'yun Babadan Ponorogo teknik penilaian yang digunakan adalah observasiu, hasil karya, dan unjuk kerja. Bentuk instrumen yang digunakan dalam penilaian di TK IT Qurrota A'yun Babadan Ponorogo sebagai berikut:

Tabel 3. Instrumen Penilaian Pembelajaran TK IT Qurrota A'yun

Babadan Ponorogo

\begin{tabular}{|c|c|c|c|}
\hline P. Pengembangan & $\mathrm{KD}$ & Indikator & Teknik Penilaian \\
\hline Nilai Agama dan & $3.1,4.1$ & mengucapkan & Observasi \\
\hline Moral & & kalimat thayyibah & \\
\hline Fisik-motorik & 4.3 & Dapat menyelesaikan tugas & Hasil karya \\
\hline Sosial-emosional & 2.6 & Dapat mengerti aturan & Observasi \\
\hline Kognitif & 4.6 & Dapat berkreatif dalam & Unjuk kerja \\
\hline
\end{tabular}




\begin{tabular}{llll}
\hline & & bermain & \\
Bahasa & 3.10 & Dapat bercerita & Observasi \\
Seni & $3.15,4.15$ & Dapat menggabar kreta api & Hasil karya \\
\hline
\end{tabular}

Teknik-teknik penilaian pembelajaran tersebut dapat berubah dan berganti sesuai dengan indikator atau aspek yang akan dinilai, akan tetapi model maupun bentuk penilaiannya tetap sama. Dalam konteks ini pendidik dituntut kreatif, cermat, dan teliti, sehingga tidak terjadi kekeliruan dalam melakukan penilaian. Adapun aspek perkembangan yang dinilai dalam Kurikulum 2013 di TK IT Qurrota A'yun Babadan Ponorogo meliputi: nilai agama dan moral, fisik-motorik, sosial-emosional, kognitif, bahasa dan seni.

Adapun kegiatan penilaian di TK IT Qurrota A'yun Babadan Ponorogo dilakukan bersamaan dengan proses pembelajaran harian dengan memberikan tanda bintang di setiap aspek perkembangan anak, kemudian diakhir pembelajaran penilaian tersebut disusun lebih rapi, supaya lebih mudah dipahami. Penilaian-penilaian harian tersebut, selanjutnya direkap dalam bentuk penilaian mingguan, dan penilaian mingguan dijadikan dasar penilaian semester. Yang menjadi kelebihan di TK Qurrota A'yun Babadan Ponorogo dalam hal penilaian ialah para pendidik selalu melaporkan hasil penilaian perkembangan peserta didik kepada orang tua di setiap akhir pekan. Oleh karena itu, orang tua dapat memantau perkembangan anaknya melalui laporan penilaian yang disampaikan kepada orang tua.

\section{Faktor Pendukung dan Penghambat Pelaksanaan}

\section{Pembelajaran Kurikulum \\ 2013 \\ Dalam pelaksanaan} pembelajaran berbasis Kurikulum 2013 di TK IT Qurrota A'yun Babadan Ponorogo terdapat beberapa faktor pendukung dan penghambat, di antaranya:
a. Faktor-faktor pendukung pelaksanaan pembelajaran Kurikulum 2013

Adapun faktor-faktor pendukung dalam pelaksanaan pembelajaran berbasis Kurikulum 2013 di TK IT Qurrota A'yun adalah:

1) Kepala sekolah TK IT Qurrota A'yun adalah salah satu intruktur Kurikulum 2013 PAUD di Kabupaten Ponorogo, sehingga secara teknis dan isi Kurikulum 2013.

2) Guru-guru di TK IT Qurrota A'yun sebagian besar masih muda dan sangat kreatif, sehingga sangat mudah dalam menyesuiakan perubahan dan kebijakan pendidikan yang baru.

3) Model pembelajaran yang digunakan sudah menggunakan sentra, sehingga sangat sesuai dengan model dan pendekatan pembelajaran Kurikulum 2013 yang menerapkan pendekatan saintifik.

b. Faktor-faktor penghambat pelaksanaan pembelajaran Kurikulum 2013

Adapun faktor-faktor yang menjadi penghambat yaitu:

1) Fasilitas pembelajaran yang ada di TK IT Qurrota A'yun masih terbatas, sehingga kurang 
maksimal dalam mengeksplorasi pembelajaran Kurikulum 2013 yang lebih menekankan pengalaman anak.

2) Administrasi pembelajaran kurang tersusun secara rapi, sehingga sedikit menyulitkan dalam penerapannya dalam pembelajaran.

\section{SIMPULAN}

Dari pembahasan tersebut dapat disimpulkan bahwa: 1) pelaksanaan pembelajaran berbasis Kurikulum 2013 di TK IT Qurrota A'yun Babadan Ponorogo telah berjalan dengan baik. Hal ini dibuktikan dengan telah terpenuhinya tahapan-tahapan pembelajaran dalam Kurikulum 2013, yaitu terdapat perencanaan pembelajaran, pelaksanaan pembelajaran, dan kegiatan penilaian pembelajaran. Selain itu, pembelajaran sehari-hari sudah menggunakan pendekatan saintifik, yakni melalui kegiatan mengamati, menanya, mencoba, menalar, dan mengkomunikasikan.

3) Faktor-faktor pendukung pelaksanaan

pembelajaran Kurikulum 2013 di TK IT Qurrota A'yun yaitu kepala sekolah yang sudah berpengalaman dalam Kurikulum 2013, guru masih muda-muda, dan sudah menggunakan model pembelajaran sentra. Adapun faktor penghambatnya yaitu fasilitas masih terbatas dan kondisi administrasi pembelajaran yang kurang tersusun rapi.

\section{DAFTAR PUSTAKA}

Arikunto, S. 2002. Prosedur Penelitian; Suatu Pendekatan Praktek. Jakarta: Rineka Cipta.

Depdiknas. Undang-Undang No. 20 Tahun 2003 tentang Sistem Pendidikan Nasional.

Fadlillah, M. 2014. Implementasi Kurikulum 2013. Yogyakarta: Ar-Ruzz Media. 2016. Model

Kurikulum Pendidikan Multikultural di Taman Kanak-Kanak. Jurnal Pembangunan Pendidikan: Fondasi Dan Aplikasi, 5 (1), 44.

http://dx.doi.org/10.21831/j ppfa.v5i1.13286

Hidayat, S. 2013. Pengembangan Kurikulum Baru. Bandung: Rosdakarya.

Kemendikbud. 2015. Kerangka Dasar dan Struktur Kurikulum 2013 PAUD. Jakarta: Dirjen PAUD. . 2015. Pedoman Penilaian PAUD. Jakarta: Dirjen PAUD

\section{Pedoman}

Penyusunan Pelaksanaan Pembelajaran PAUD. Jakarta: Dirjen PAUD. 2015. Pengenalan Kurikulum PAUD. Jakarta: Dirjen PAUD. .2014. Permendikbud No. 137 Tahun 2014 tentang Standar Nasional Pendidikan Anak Usia Dini. .2014. Permendikbud No. 146 Tahun 2014 tentang 
M. Fadlillah, PELAKSANAAN PEMBELAJARAN BERBASIS KURIKULUM 2013 DI TK IT QURROTA A'YUN BABADAN PONOROGO. Early Childhood Vol. 2 No. 1, Mei 2018

Kurikulum 2013 Pendidikan

Anak Usia Dini.

Sudijono, A. 2005. Pengantar Evaluasi Pendidikan.

Jakarta: Rajawali Press.

Sugiyono. 2011. Metode Penelitian Kuantitatif, Kualitatif, dan

$R \& D$. Bandung: Alfabeta. 